\title{
Sensitive detection of novel Indian isolate of BTV 21 using ns1 gene based real-time PCR assay
}

\author{
T. M. Vishwaradhya, P. Minakshi, Koushlesh Ranjan, Supriya, Pawan Kumar and Gaya Prasad
}

Department of Animal Biotechnology,

LLR University of Veterinary and Animal Sciences, Hisar, Haryana, 125004 India

Corresponding author: P. Minakshi, email: minakshi.abt@gmail.com

Received: 01-02-2013, Revised: 29-03-2013, Accepted: 03-04-2013, Published online: 05-06-2013

How to cite this article: Vishwaradhya TM, Minakshi P, Ranjan K, Supriya, Kumar P and Prasad G (2013) Sensitive detection of novel Indian isolate of BTV 21 using nsl gene based real-time PCR assay, Vet World 6(8): 554-557, doi: 10.5455/ vetworld. 2013.554-557

\begin{abstract}
Aim: The study was conducted to develop ns 1 gene based sensitive real-time reverse transcriptase PCR (real-time RT-PCR) assay for diagnosis of India isolates of bluetongue virus (BTV).

Materials and Methods: The BTV serotype 21 isolate (KMNO7) was isolated from Andhra Pradesh and propagated in BHK21 cell line in our laboratory. The Nucleic acid (dsRNA) of virus was extracted using Trizol method and cDNA was prepared using a standard protocol. The cDNA was allowed to ns1 gene based group specific PCR to confirm the isolate as BTV. The viral RNA was diluted 10 folds and the detection limit of ns 1 gene based RT-PCR was determined. Finally the 10fold diluted viral RNA was subjected to real-time RT-PCR using ns1 gene primer and Taq man probe to standardized the reaction and determine the detection limit.

Results: The ns 1 gene based group specific PCR showed a single 366 bp amplicon in agarose gel electrophoresis confirmed the sample as BTV. The ns 1 gene RT-PCR using 10 fold diluted viral RNA showed the detection limit of 70.0 fg (equivalent to $3.3 \times 10^{3}$ target copies of ns 1 gene) per reaction in $1 \%$ agarose gel electrophoresis. The ns 1 gene based real time RT-PCR was successfully standardized and the detection limit was found to be $7.0 \mathrm{fg}$ (equivalent to $3.3 \times 10^{2}$ target copies of ns 1 gene) per reaction.
\end{abstract}

Conclusion: The ns1 gene based real-time RT-PCR was successfully standardized and it was found to be 10 times more sensitive than conventional RT-PCR.

Key words: bluetongue, BTV21, ns1 gene, real-time RT-PCR, RT-PCR

\section{Introduction}

Bluetongue (BT) is an economically important, infectious, non-contagious, insect transmitted viral disease of domestic and wild ruminants [1]. The virus is prone to frequent mutations and genetic reassortment leading to emergence of several serotypes [2]. So far 24 serotypes have been reported from all over the world [3]. However, two more serotypes i.e. BTV 25 from Switzerland [4] and BTV 26 from Kuwait [5] have been, reported recently. In India 21 different BTV serotypes have been reported from different parts based upon serum neutralization and virus isolation [6]. However, BTV serotype 21 has been reported from West Bengal state of India recently [7].

To detect effectively BT disease, nucleic acid based methods have been developed and evaluated for group specific detection. Although conventional reverse transcriptase polymerase chain reaction (RTPCR) has advantages over hybridization reaction with increased sensitivity but it is almost impossible to quantify BTV nucleic acid accurately by regular and multiplex PCR procedures. The real-time RT-PCR has potential to replace conventional RT-PCR in the field

This article is an open access article licensed under the terms of the Creative Commons Attribution License (http://creativecommons. org/licenses/by/2.0) which permits unrestricted use, distribution and reproduction in any medium, provided the work is properly cited. of diagnostic and research. The potential of this format to provide sensitive, specific and rapid detection and quantification of viral RNA has made it an indispensable tool for state-of-the-art diagnostics of important animal viral pathogens [8]. Integration of these assays into automated liquid handling platforms for nucleic acid extraction increases the rate and standardization of sample throughput and decreases the potential for cross-contamination.

By real-time RT-PCR the highly conserved genome segment of ns 1 can be targeted to detect all the 24 BTV serotypes, as well as geographic variants within the individual serotype. The real-time RT-PCR based assays are capable of rapid screening of field samples of BTV [9]. A new primer-probe energy transfer (PriProET) based real-time RT-PCR assay was developed recently for early and rapid detection of all 24 BTV serotypes along with other emerging strains of BTV [10]. A duplex real-time RT-PCR for the detection of bluetongue virus in bovine semen has been developed [11]. Although, the real-time PCR assay is highly sensitive but it can be affected by the source of the viral nucleic acid. Because, the host animal species can affect the viral nucleic acid extraction and in turn affect the detection limit of viral nucleic acid through RT real-time PCR [12]. The real-time RT-PCR is highly sensitive having high range of detection and can 


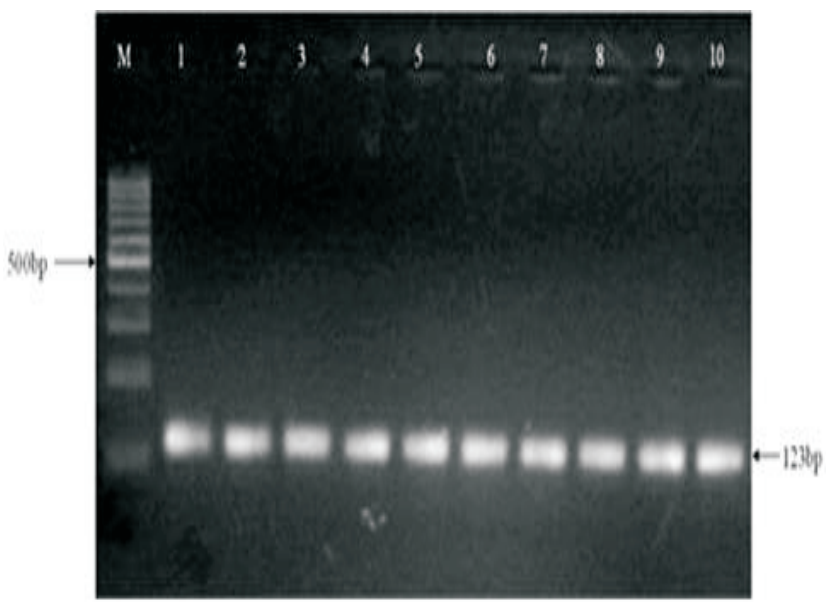

Figure-1. RT-PCR using nsl gene specific primers to generate 123 bp product. Lanes: M- 100bp ladder; 1- positive control 2 -KMNO7 (BTV-21); The numbers on sides indicate size of PCR product in base pair

be used for quantification of template also.

Here we report development and evaluation of a TaqMan probe based real-time RT-PCR assay targeting ns1 gene for detection of novel Indian BTV-21 serotype which could be the first report in India to the best of our knowledge.

\section{Materials and Methods}

Bluetongue virus isolate: The novel Indian isolate of BTV-21 (KMNO7) originated from Andhra Pradesh, India was grown in Baby hamster kidney-21 (BHK-21) cell line and used for raising virus stock for RNA isolation.

Extraction of viral RNA and cDNA preparation: The dsRNA from cell culture grown viruses was extracted by standard procedure used in our laboratory [13]. The extracted RNA was confirmed as BTV by RNA-PAGE analysis. The viral RNA was further confirmed as BTV by amplification of ns 1 gene by RT-PCR. Reverse transcription was carried out in a $20 \mu \mathrm{l}$ reaction mixture using the following components: $1.2 \mu \mathrm{g} / \mu \mathrm{l}$ viral dsRNA, $1.5 \mu \mathrm{l}$ DMSO, $30 \mathrm{pmol}$ random primers. The mixture was heated at $99^{\circ} \mathrm{C}$ for $5 \mathrm{~min}$ in thermal cycler (Biorad i-cycler, USA), snap chilled on ice and then the following reagents were added: $1 \mu \mathrm{l}$ of $200 \mathrm{units} / \mu \mathrm{M}$ MoMuLV-RT (Promega, USA), 1X RT buffer, $0.5 \mu 1100$ $\mathrm{mM}$ dNTPs. After allowing the primers to anneal at $25^{\circ} \mathrm{C}$ for $10 \mathrm{~min}$, reverse transcription was carried out at $37^{\circ} \mathrm{C}$ for $60 \mathrm{~min}$ in thermal cycler. The reverse transcriptase was heat inactivated at $90^{\circ} \mathrm{C}$ for $10 \mathrm{~min}$.

Primers and probe for ns1 gene specific real-time PCR and RT-PCR: The group specific ns1 gene based primer was used to confirm the sample as BTV [14]. The same primer was used with serially 10 fold diluted sample to determine the detection limit of ns1 gene based RTPCR. For real-time PCR reaction the ns 1 gene specific primers pair forward (606-631: 5'-GTTGAGA GACA AATTAACACATGTCC-3') and reverse (705-723:5'AATGCTTCG CAAAAT CAT CC AT-3') along with fluorogenic TaqMan-MGB probe corresponding to

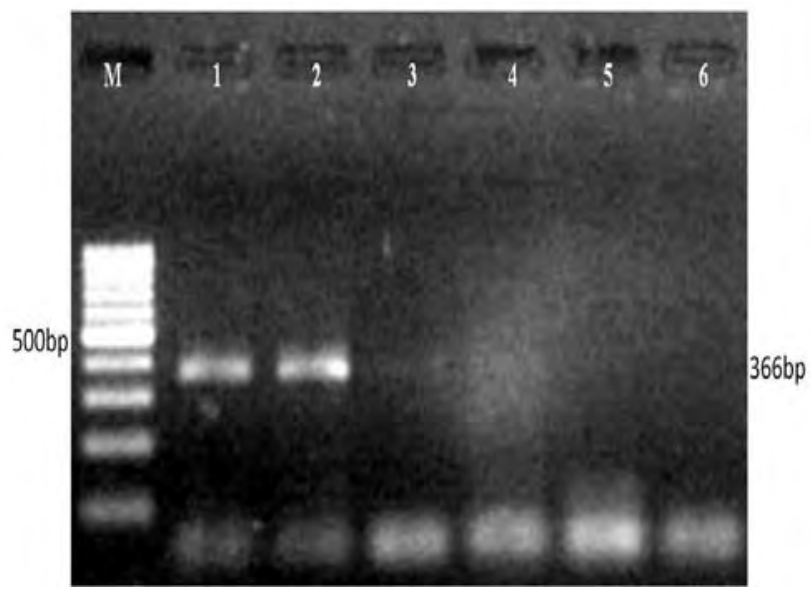

Figure-2. Limit of detection of RNA of isolate KMNO7 (BTV-21) using ns1 gene specific RT-PCR. Lanes: M- 100 bp ladder; 1- 70.0pg; 2 7.0pg; 3- 0.70pg; 4- 0.070pg; 5- 0.007 pg and 6- 0.0007pg.

676-692 region (6-FAM-CGAT TCAGCTGATCAATMGB) were synthesized [15].

Ns1 gene specific RT-PCR : The cDNA was amplified targeting the non-structural (ns1) gene specific primer pairs in a $25 \mu \mathrm{l}$ using the following conditions: $25 \mathrm{pM}$ primer (forward and reverse both), $2 \mu$ l of cDNA, 200 $\mu \mathrm{M}$ dNTP, 6\% DMSO, $1.5 \mathrm{mM} \mathrm{MgCl} 2$ and $2.5 \mathrm{U}$ of Taq polymerase. The initial denaturation step was done at $95^{\circ} \mathrm{C}$ for $3 \mathrm{~min}$ for all primers, three step cyclic denaturation at $94^{\circ} \mathrm{C}$ for 30 seconds, annealing temperature of $58^{\circ} \mathrm{C}$ extension step was at $72^{\circ} \mathrm{C}$ for one min and final extension at $72^{\circ} \mathrm{C}$ for $8 \mathrm{~min}$. The $\mathrm{ns} 1$ gene based primer of real-time PCR was also subjected to RT-PCR to confirm the specificity of the primer to ns 1 gene.

The real-time RT-PCR: The cDNA was used for real time PCR using ns 1 gene specific primers and probe in $20 \mu \mathrm{M}$ concentration which yielded better $\mathrm{Ct}$ value on standardization. A $25 \mu \mathrm{l}$ reaction was set having following components: Universal Master Mix (13.0 $\mu \mathrm{l})$, forward and reverse primers (8pM), TaqMan probe $(8 \mathrm{pM}), \mathrm{cDNA}(2.0 \mu \mathrm{l})$. The above reaction mixture was transferred to the 96 well optical plate and covered with optical cover. The reaction was carried out in ABI 7500 Std. version (1.4) using the thermal condition for 40 cycles: initial denaturation step at $95^{\circ} \mathrm{C}$ for $10 \mathrm{~min}$, three step of cyclic denaturation at $94^{\circ} \mathrm{C}$ for 15 seconds, annealing temperature of $54^{\circ} \mathrm{C}$ for 15 seconds, extension step was carried out at $61^{\circ} \mathrm{C}$ for $1 \mathrm{~min}$ and final extension at $61^{\circ} \mathrm{C}$ for $5 \mathrm{~min}$.

\section{Results and Discussion}

The real-time RT-PCR is eco-friendly and less health hazardous as well as economical as it avoids the use of agarose gel electrophoresis (having harmful ethidium bromide), so decreasing the risks of environmental contamination. The assay is suitable for large scale sample testing and detection of BTV from various biological samples such as blood, semen etc. as well as adapted in various cell lines such as BHK-21, 
Table-1. Determination of detection limit in 10 fold dilution of RNA of BTV isolate KMNO7 (BTV-21)

\begin{tabular}{llll}
\hline Sr. No. & Dilution & Concentration of RNA & Ct value \\
\hline 1 & $10^{-1}$ & $70.0 \mathrm{pg}$ & 25.5665 \\
2 & $10^{-2}$ & $7.0 \mathrm{pg}$ & 27.6775 \\
3 & $10^{-3}$ & $0.70 \mathrm{pg}$ & 33.7183 \\
4 & $10^{-4}$ & $0.070 \mathrm{pg}$ & 34.6357 \\
5 & $10^{-5}$ & $0.0070 \mathrm{pg}$ & 37.2845 \\
6 & $10^{-6}$ & $0.00070 \mathrm{pg}$ & Undetected \\
7 & $10^{-7}$ & $0.000070 \mathrm{pg}$ & Undetected \\
8 & NTC & - & Undetected \\
\hline
\end{tabular}

Vero and C6/36. In the present study, BHK-21 cell line was used for propagation of novel Indian isolate of BTV 21. The isolate induced characteristic cytopathic effect (CPE) such as rounding of cells, fusion, foamy degeneration and death of infected cells resulting in detachment of cells from the surface of culture bottles.

The RNA-PAGE analysis revealed classical 10 segments with 3:3:3:1 migration pattern which is characteristic to BTV as reported earlier [16]. RNAPAGE has been used not only to identify and detect BTV in samples but also to analyze genomic diversity within and between serotypes and re-assortments in mixed infection $[16,17]$. BTV-21 yielded an expected intense band of 123 bp without any non-specific amplification using group specific primers targeting ns1 gene (designed for real time PCR) by RT-PCR (Figure-1). The novel isolate KMNO7 (BTV-21) was subjected to RT-PCR amplification of ns1 gene with serially 10 fold diluted viral RNA with initial RNA concentration of $0.7 \mathrm{ng} / \mu \mathrm{l}$ and the expected $366 \mathrm{bp}$ band was observed up to the 4th dilution corresponding to $70.0 \mathrm{fg}$ of RNA (equivalent to $3.3 \times 10^{3}$ target copies of ns1 gene) (Figure-2). The earlier workers reported that the primers complimentarily targeting the $5^{\prime}$ terminus of segment 5 encoding ns 1 gene might be suitable for development of group specific diagnosis of BTV by RT-PCR [18]. The group specific ns1 gene of genomic segment 5 was targeted for the conventional RT- PCR and real-time RT-PCR as the ns1 gene is highly conserved across the all serotypes.

The isolate KMNO7 (BTV-21) with measured concentration of RNA of $0.7 \mathrm{ng} / \mu 1$ was also serially 10 fold diluted and reverse transcribed to produce cDNA. The corresponding cDNA was used for real-time RTPCR. The first dilution of RNA showed Ct value at 26 cycle corresponding to $70 \mathrm{pg} / \mu \mathrm{l}$. As dilution level increased the $\mathrm{Ct}$ value also increased for the corresponding dilution. The minimum amount of RNA measured by the assay was up to level of fifth dilution $\left(10^{-5}\right)$ corresponding to $7 \mathrm{fg} / \mu 1$ (equivalent to $3.3 \times 10^{2}$ target copies of ns 1 gene) which was at the 38 cycle.

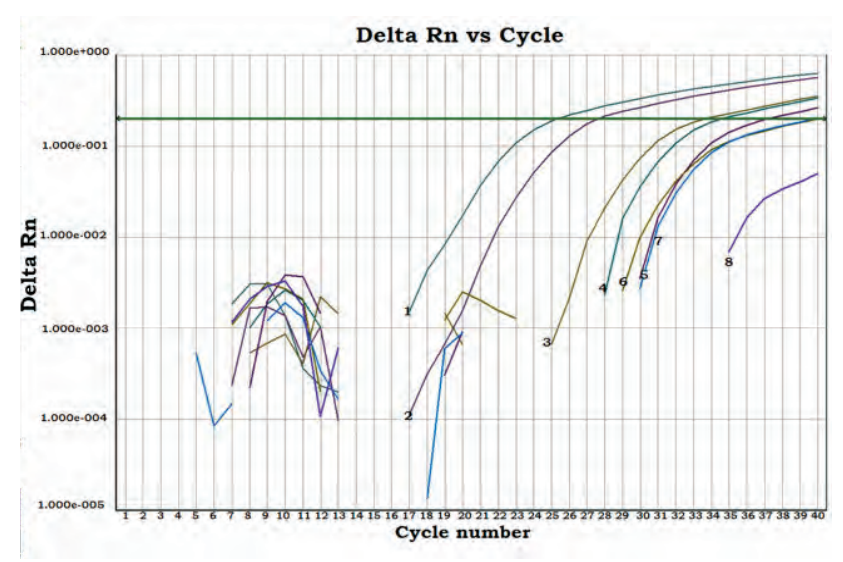

Figure-3. Real-Time RT-PCR threshold curves and limit of detection of isolate KMNO4 in 10 fold dilution Label: $1-70 \mathrm{pg} ; 2$ 7.0pg; 3-0.7pg; 4-0.07pg; 5-7.0 pg; 6-0.7fg; 7-0.07fg and 8NTC. The number $1-10$ indicates the 10 fold (10-1 to 10-7) dilution of the template.

The dilutions of RNA which was showing $\mathrm{Ct}$ value below 40 are considered as positive (Table-1, Figure$3)$. The reaction mixture containing no template is not showing any $\mathrm{Ct}$ value below 40 and was considered as negative.

Thus, the real-time PCR had lower limit (7.0 fg) of detection compared to conventional RT-PCR (70.0 fg). By comparing the results of both assays it was revealed that the real-time RT-PCR has been found to about 10 times more sensitive as compared to the conventional RT-PCR. With a view to develop highly sensitive assays for the detection of BTV, it is necessary to determine the threshold sensitivity of RTPCR. The genome segment 10 based RT-PCR detection limit for BTV was reported as little as $100 \mathrm{fg}$ to $1 \mathrm{pg}$ of BTV RNA, which is equivalent to $5 \times 10^{3}$ to $5 \times 10^{4}$ viral particles [19].

Earlier, different gene specific RT-PCR were developed for diagnosis of BTV from various biological samples. The ns1 gene based nested RTPCR was one of them and its detection limit was 1 plaque-forming unit (pfu) of BTV in Culicoides midges [20]. For retrospective diagnosis of BTV in frozen semen and fixed tissue samples the vp3 gene specific RT-PCR was developed with the threshold detection limit with 0.75 to $7.5 \mathrm{pfu}$ of BTV on fresh tissues [21]. Later on, the more specific and sensitive real-time PCR technique was developed for BTV diagnosis. The detection limit for real-time RT-PCR to detect bluetongue virus in blood samples by TaqMan probe and ns1 gene specific primer was found to be 0.005 to $0.05 \mathrm{TCID}_{50} / \mathrm{ml}$ [22]. Similarly the detection limit of $0.1 \mathrm{TCID} 50 / \mathrm{ml}$ was reported using TaqMan probe and ns1 gene specific primer in BHK-21 cell culture adapted BTV [23]. The segment 10 based realtime RT-PCR assays based on the primer-probe energy transfer (PriProET) can detect 10-100 target copies of viral RNA of all the 24 serotypes of BTV [10]. Another real-time PCR assay showed the detection limit of less than 10 copies of BTV Seg-1 ssRNA [9].

In future extensive evaluation of group specific 
real-time RT-PCR assay targeting ns1 gene with serotypes and isolates from varied geographical locations or regions would strengthen their serogroup specificity. There is a further scope for developing quantitative real-time RT-PCR for BTV to know the viral load in samples. Large scale testing of field samples would be useful in better extending the application of these assays at field level.

\section{Conclusion}

The novel isolate was confirmed as BTV based on ns1 gene specific RT-PCR. It is clear from the present study that real-time PCR is more sensitive and superior to conventional RT-PCR. The ns1 gene based real-time RT-PCR was found to be 10 times more sensitive than conventional RT-PCR. There has been no report on diagnosis of BTV using real-time RT-PCR for Indian isolates and it is the first report describing such phenomenon.

\section{Authors' contribution}

All the authors contributed equally. All authors read and approved the final manuscript

\section{Acknowledgements}

The authors are thankful to All India Network Programme on BT (AINP-BT), funded by Indian Council of Agriculture Research, New Delhi for financial support and the Department of Animal Biotechnolgy, LLRUVAS, Hisar for providing research facilities.

\section{Competing interests}

The authors declare that they have no competing interest.

\section{References}

1. Jessup, D.A., Osborn, B.I. and Heuschele, W.P. (1984) Bluetongue in California's Wild Ruminants: Distribution and Pathology, Proceedings of the Annual Meeting of the U.S. Animal Health Assoc. 616-630.

2. Samal, S. K., Livingston, C. W., McConnell, S. and Ramig, R. F. (1987) Analysis of mixed infection of sheep with bluetongue virus serotypes 10 and 17: evidence for genetic reassortment in the vertebrate host, J. Virol. 61:1086-1091.

3. Gibbs, E. P. J. and Greiner, E. C. (1994) The epidemiology of bluetongue. Comp. Immuno. Micro. Infect. Dis. 17:207-220.

4. Hofmann, M. A., Renzullo, S., Mader, M., Chaignat, V., Worwa, G. and Thuer, B. (2008) Genetic Characterization of Toggenburg Orbivirus, a New Bluetongue Virus, from Goats, Switzerland, Emerg. Infect. Dis.14 (12): 1855-1861.

5. Maan, S., Maan, N.S., Nomikou, K., Eva, V., Bankowska, K.B., Manjunatha, B.N., Houssam, A. and Mertens, P.P.C. (2011) Complete Genome Characterisation of a Novel 26th Bluetongue Virus Serotype from Kuwait, Plos One., 6(10):1 -11.

6. Prasad, G., Minakshi and Malik, Y (2007) 'Bluetongue' (Eds: G. Prasad, Minakshi and Yashpal Malik), A book published by Indian Council of Agricultural Research, New Delhi.

7. Jordar, S. N., Lodh, C., Chakrabarti, A., Baksi, S. and Aich, R. (2009) Isolation of Bluetongue virus serotype 15 and 21 in West Bengal, India. Vet. Rec. 165: 751-752.

8. Black, E. M., Lowings, J. P., Smith, J., Heaton, P. R. and McElhinney, L. M. (2002) A rapid RT-PCR method to differentiate six established genotypes of rabies and rabies- related viruses using TaqMan technology, J. Virol. Methods. 105:25-35.

9. Shaw, A. E., Monaghan, P., Alpar, H. O., Anthony, S., Darpel, K. E., Batten, C. A., Guercio, A., Alimen, G., Vitale, M., Banakowska, K., Carpenter, S., Jones, H., Oura, C. A. L., King, D. P., Elliot, H., Mellor, P. S. and Mertens, P. P. C. (2007) Development and initial evaluation of a real-time RTPCR assay to detect bluetongue virus genome segment $1, J$. Virol. Methods. 145: 115-126.

10. LeBlanca, N., Rasmussen, T. B., Fernandez, J., Sailleau, C., Rasmussen, L. D., Uttenthal, A., Zientara, S., Belak, S. and Hakhverdyan, M (2010) Development of a real-time RTPCR assay based on primer-probe energy transfer for the detection of all serotypes of bluetongue virus, J. Virol. Methods. 167:165-171.

11. Vanbinst, T.,Vandenbussche, F., Dernelle, E. and Clercq, K. D. (2010) A duplex real-time RT-PCR for the detection of bluetongue virus in bovine semen, J. Virol. Methods. 169:162-168.

12. Brito, B, P., Gardner, I. A., Hietala, S. K. and Crossley, B.M. (2011) Variation in Bluetongue virus real-time reverse transcription polymerase chain reaction assay results in blood samples of sheep, cattle, and alpaca, J. Vet. Diagn. Invest. 23:753-756.

13. Minakshi, P., Singh, R., Ranjan, K., Kumar, P., Joshi, C. G., Reddy, Y. K. M. and Prasad, G. (2012) Complete genome sequence of bluetongue virus serotype 16 of goat origin from India. J. Virol. 86:8337-8338.

14. Kovi RC, Dahiya S, Minakshi and Prasad G. (2005) Evaluation of new primers targeting serogroup specific genes for detection of bluetongue viruses by RT-PCR. Indian J. Microbiol. 45(2); 103-119.

15. Jimenez-Clavero, M. A., Aguero, M., San Miguel, E., Mayoral, T., Lopez, M. C., Ruano, M. J., Romero, E., Monaco, F., Polci, A., Savini, G. and Gomez-Tejedor, C. (2006) High throughput detection of bluetongue virus by a new real-time fluorogenic reverse transcription-polymerase chain reaction: application on clinical samples from current Mediterranean outbreaks. J. Vet. Diag. Invest. 18: 7-17.

16. Ranjan, K., Minakshi, P., Shafiq, M., Pawan, K. and Prasad, G. (2011) Genetic Diversity of Indian Isolates of Bluetongue Virus 16, Int. J. Appl. Eng. Res. 6: 884-887.

17. Prasad, G., Minakshi, Maan, S. and Malik, Y. (1998b). Genomic diversity in Indian isolates of bluetongue virus serotype 1, Indian. J. Microbiol. 38: 161-163.

18. Prasad, G., Minakshi, Malik, Y. and Maan, S. (1999) RT-PCR and its detection limit for cell culture grown bluetongue virus1 using NSI gene specific primers, Indian J. Exp. Biol. 37: 1255-1258.

19. Akita, G. Y., Chinsangaram, J., Osburn, B. I., Ianconescu, M. and Kaufman. R. (1992) Detection of bluetongue virus serogroup by polymerase chain reaction, J. Vet. Diagn. Invest. 4: 400-405.

20. Wilson, W. C. and Chase, C. C. L. (1993) Nested and multiplex polymerase chain-reactions for the identification of bluetongue virus-infection in the biting midge, Culicoides variipennis, J. Virol. Methods. 45: 39-47.

21. Parsonson, I. M. and McVoll, K. A. (1995) Retrospective diagnosis of bluetongue virus in stored frozen and fixed tissue samples using PCR, Vet. Microbiol. 46:143-149.

22. Polci, A., Camma, C., Serini, S., Di Gialleonardo, L., Monaco, F. and Savini, G. (2007) Real-time polymerase chain reaction to detect bluetongue virus in blood samples, Vet. Italiana. 43: 77-87.

23. Yin, H. Q., Zhang, H., Shi, L. J., Yang, S., Zhang, G. P., Wang, S. Q. and Zhang J.G. (2010) Detection and quantitation of bluetongue virus serotypes by a TaqMan probe-based real-time RT-PCR and differentiation from epizootic hemorrhagic disease virus, J. Virol. Methods. 168:237-241. 